\title{
Historická sociologie jako dobrodružství poznání
}

Nechystám se tvrdit nic převratného, jen konstatuji několik víceméně známých věcí. Patrně každý, kdo se považuje za dostatečně inteligentního, by v dnešním vědou prostoupeném, někdy až obklíčeném světě chtěl výrazně zasáhnout do jejího vývoje. Proniknout s její pomocí do tajů lidského bytí a mysli. Ovšem v takové chvíli podobně ambiciózní snílek okamžitě naráží na své předchůdce a protichůdce, badatele a badatelky, kteří již před ním učinili určitý průlom na př́íslušném vědeckém poli, at' už s využitím nových poznatků, nebo „pouhým“ přeskupením těch starších. Hned na počátku nám tato často nechtěná setkání mohou sebrat vítr z plachet. Někdo je schopen vyčerpat určité téma z hlediska celku i detailů, takže na ostatní zbydou jen paběrky. Stranou se pak nutně ocitá veškerá touha tvůrců po originalitě. Pokud něco zbývá, pak je to především nutnost „trefit se“ i s vlastním málem do rytmu doby, rozčeřit alespoň trochu rostoucí vlny inovací. Na důležitosti tím nabývá šíře záběru a určitá snaha o syntetizující obecnost.

Do badatelské hry však může vstoupit rovněž prvek tajuplné a neznámé, do nejasné budoucnosti směřující improvizace, přičemž výsledek nemusí být hned perfektní. To ani v nejmenším nevadí, právě naopak. Ocitáme se totiž na prahu nepředpokládaného stavu, otevíráme stavidla pro proud mimořádných a nepředvídaných štastných náhod, nečekaných shod okolností. Krátce a metaforicky řečeno, máme co do činění s tzv. serendipitou. Tento fenomén spojený s určitou „polohou mysli“ a zároveň schopností se bezpochyby uplatňuje i v dějinách inovací; jako instruktivní příklad se uvádí objev penicilinu Alexandrem Flemingem roku 1928. V medicíně se ostatně s termínem serendipita operuje dosti frekventovaně s nadějí, že se tímto způsobem nakonec přece jen podaří objevit léky proti nevyléčitelným, kancerogenním chorobám. Na poli sociologie se k pojmu serendipita vyjádřil Robert K. Merton, a sice v tom smyslu, že badatel má při analýze dat a poznatků věnovat pozornost i drobným nesrovnalostem, které neodpovídají tomu, co by se dalo „normálně“ očekávat. Právě takové drobnosti na okraji výzkumu nás totiž mohou přivést $\mathrm{k}$ velkému objevu.

Jak již bylo řečeno v úvodu, nejeden $\mathrm{z}$ nás by chtěl svět oslnit svými objevy a vynálezy. Jako prŕklad snad mohu uvést vlastní opakovanou snovou zkušenost, kdy jsem byl hodně blízko řešení, ale neudržel jsem v paměti onen kýžený výrok, který tak elegantně kloubil vědecké myšlení s myšlením spontánním. Možná jsem se ale jen zaleknul toho, že všechno působilo nějak moc „přidrzle“. S určitou nadsázkou, která ke snům patří, se zdálo, jakoby v tom byl namočený dokonce sám Hermés se svou hermeneutikou. Možná že ani trochu, sám nedokážu říct. Ten bájný Hermés, ukazatel na rozcestí, to on byl tak přidrzlý a ještě se mi vysmíval. Ponechat vše v půli cesty, jakoby napospas Hermovi, a s tím pak trpělivě pracovat. Na tom spočívá i liminalita ve vědě ale i v umění. Jedním z jejích nanejvýš přesvědčivých prŕíkladů může být jazz, hudební styl, který se ve 20. století vyvinul překvapivou 
rychlostí. Běží o velký mix tzv. nízkého a vysokého umění, takže anglická fráze „jazz it“, jakkoliv obtížně přeložitelná, působí dosti jasně a srozumitelně. Takto prý byli oslovováni hudebníci; měli hrát se zápalem. Jde snad o pobídku?

Málo je známo, že významný britský historik Eric Hobsbawm (1917-2012) uveřejnil pod pseudonymem Francis Newton [1959] poučenou publikaci o jazzové scéně. (V českém překladu se objevila roku 1973.) Zmíněná kniha osciluje mezi sociální historií a sociologií tohoto hudebního žánru. Nebudu se tu pouštět do podrobných úvah, jen podotknu, že Hobsbawm se zabýval hudbou jazzového okruhu obecně, a to včetně prolínání s ostatními druhy umění, dále se věnoval typickým nástrojům, a konečně pak hudebnímu přínosu jazzu. Jeho pozornosti neunikla ani obchodní stránka (jazzový „byznys“), hudebníci a jejich obecenstvo apod.

Z českých autorů podal ve své době výstižnou charakteristiku jazzu hudební skladatel Jan Rychlík (1916-1964). Uvažoval třebas takto: „Severní Amerika nastupuje svou komerční ofenzívu. Její nakladatelské podniky mají svou zvláštní tradici. Nejmocnější z nich se soustředují na Tin Pan Alley. Autor šlágru či písně nemusí znát ani noty. K tomu jsou zvláštní zaměstnanci, klavíristé a upravovatelé. Nakladateli jde hlavně o nápad, který by ,chytl'. A tak autor zahvízdá či přezpívá melodii, zaměstnanec nakladatele ji zapíše a jiní ji zpracují. Krom toho se utěšeně vyvíjí průmysl gramofonový, jeho technika se stále zdokonaluje, počet nahrávek vzrůstá a jejich jakost se zlepšuje. Vznikají slavné šlágry, které žijí dodnes a budou ještě dlouho žít" [Rychlík 1959: 8]. Zmíněný Jan Rychlík se ještě v samostatných kapitolách vyslovil např́klad k improvizaci a specifické funkci hudebních nástrojů. Určitě i za hranicí Rychlíkovy podnětné knihy zbývají další a další fazety jazzu, jež by bylo možno trefně glosovat. Ale nejsme hudební časopis; pro kontextovost problematiky je prozatím řečené plně postačující. Nemohu ovšem při této př́ležitosti nepřiznat: jazz mne náramně baví...

Možná poněkud překvapivě si nyní dovolím konstatovat, že shora naznačené předpoklady lze aplikovat také na obor historická sociologie, a to konkrétně tak, že by tato teoretická věda, pohybující se mezi sociologií a historiografí́, měla přinášet i praktické aplikace. Může nakonec svým způsobem představovat jakousi „nedisciplinovanou disciplínu“. Není ostatně žádným tajemstvím, že kvalita jazzové improvizace je vždy př́imo úměrná množství času stráveného zcela rutinním, zdánlivě netvưrčím a nudným nástrojovým, případně kapelovým cvičením...

Dále by mohla přijít na přetřes i ekonomická sociologie, která bude muset být $\mathrm{z}$ holé nutnosti rovněž dosti „praktická“. Ukazuje se zkrátka, že nejenom v sociálních vědách se dnes stále něco modifikuje, což s sebou přináší ne vždy vítané změny, úpravy, přizpůsobení, omezení apod. Značnou roli potom bude hrát různá míra tolerovatelné variability, jak na straně teorie, tak z hlediska praktických aplikací. Nadto lze v podobném duchu počítat rovněž s kompozičními postupy vytvářejícími koláž (patchwork), často na první pohled disparátních elementů. V př́ípadě zapojení „narativního paradigmatu“ to pak znamená akceptování cizích diskurzů, tj. citací, parodií, aluzí, ironických transformací aj.

Jestliže bychom posunuli naše úvahy o vědecké a technické kreativitě na ještě o něco abstraktnější, obecnější úroveň, zjistíme, že inovace vznikají bud' uvnitř kultury (objevy a vynálezy), nebo přicházejí z vnějšku. Potom se jedná o tzv. „kulturní výpůjčky“ (borowing), přičemž bývá konstatováno, že přibližně $90 \%$ světa je ovlivněno zbývajícími $10 \%$. 
Během posledních dvou desetiletí se stále více operuje s konceptem flow (čili plynutí, proud), který stanovil americký psycholog mad’arského původu Mihaly Csikszentmihályi. Svým způsobem se dokonce stala $\mathrm{z}$ „plynutí, podobně jako z řady jiných původně inovativních, následně mediálně až př́liš frekventovaných konceptů, jakási postmoderní móda. Nicméně, podle jmenovaného, mezinárodně uznávaného vědce lze tento vrcholný stav navodit maximálním soustředěním; dojde přitom zároveň ke specifickému přeladění mysli i těla, načež se daří skloubit efektivní výkon a pocit štěstí. Domnívám se ovšem, že mimořádné výkony doprovázené pocitem blaženosti se navzdory optimistickým představám samotného Csikszentmihályiho a jeho příznivců neobjevují zas až tak často... Pojem flow využil ve svém bádání i sociální antropolog a ritualista Victor Turner (1920-1983). Mimochodem, tentýž Victor Turner [1982; 1983] prosazoval také rituál a drama jako veřejnou formu liminality.

Na pomyslné podium odvážně jazzující vědy můžeme nyní povolat i Georga Simmela (1858-1918) nejen s jeho koncepcí dobrodružství. Snad některý poučený čtenář našeho žurnálu zareaguje a doplní vlastními postřehy inspirativní glosu Jiřího Šubrta, věnovanou stému výročí úmrtí tohoto významného sociologa a filozofa. Publikujeme ji v přítomném čísle. Já sám jsem si bez udání zdroje onehdy poznamenal Simmelův postřeh, že sociální skupiny se chovají mnohem kritičtěji k renegátům než k cizím členům, i když tito stojí vůči nim ve znepřáteleném postavení. Platí to rovněž pro oblast skupinové ideologie: pro skupinu je nepř́ítelem jak renegát, který rozkládá její systémy víry, cílů a hodnot, tak heretik, jenž chce dosahovat uznávaných cílů jinými prostředky. Ve speciálním eseji Georg Simmel [1997: 44-60] pojednal o již zmíněném dobrodružství, přičemž v něm podal výstižnou charakteristiku tohoto fenoménu. Ve stručnosti ještě dodejme, že sociologií dobrodružství v návaznosti na Simmela a Michela Maffesoliho se ve své studii zabývala také slovenská socioložka Dilbar Alijeva [2015].

Pokud jde o právě publikovaný svazek Historické sociologie, sešlo se pár zajímavých textů různého zaměření, jak obecnějšího rázu, tak i pokrývajících detailnější oblasti studia. V angličtině publikujeme nápaditou studii egyptoložky Valérie Wyns (univerzita Loewen) o štěstí v rámci Kleopatřina království. Autorka v ní zkoumala hlavně kvalitu života v helénistickém Egyptě. Historik hospodářských dějin Ivan Jakubec nastínil společenskou dimenzi automobilismu. Přichází s tezí, že $\mathrm{k}$ automobilismu je potřebí přistupovat $\mathrm{v}$ interdisciplinární perspektivě, a to jako k technickému výrobku a dopravnímu prostředku, ale též k sociálnímu fenoménu, v neposlední řadě coby symbolu a kulturní inspiraci. Vratislav Kozák se podrobně vyjádřil k „etablování sociologie v českém prostředí T. G. Masarykem“. UNRRA a uprchlické krize po druhé světové válce byly předmětem důkladného bádání Jany Frydryškové Yasin. Podrobné archívní studium podstoupil Jan Koumar, když se zabýval konfiskací majetku českých Židů v poválečném Československu (na př́ikladu zámku a velkostatku Puklice). Je pro nás potěšující, že někteří zahraniční autoři vyslovují přání, aby jejich stat’ nebo přednáška byla publikována v českém překladu. Tak Dirk Kaesler z univerzity Marburgu proslovil a v české verzi v aktuálním čísle našim čtenářům předkládá přednášku na téma „Univerzální racionalizace: Velké vyprávění Maxe Webera“.

Vraṫme se ted' na chvíli k obsahu předchozího anglického čísla Historické sociologie z roku 2018, jehož editorem byl Johann Pall Arnason. Podařilo se mu finalizovat speciální sekci čtyř důkladných studií věnovaných 130. výročí Velké francouzské revoluce. Tato skutečnost svědčí o náležité erudici autorů spojených s naším časopisem, zbývá jen dodat, 
že hlavní podnět v tomto směru vyšel z univerzity v Exeteru. Taktéž „domácí“ Johann Pall Arnason však ve svých příspěvcích (editorialu, eseji i dvojrecenzi) přináší řadu zcela původních postřehů a ústrojně se dopracovává syntetizujícího pohledu.

Tímto způsobem se nám opakovaně daří zajistit mezinárodní a oborový přesah, navíc odpadají obavy z marginalizace studií vzhledem k jazykové bariéře. Velký podíl na úspěšném vydání tohoto čísla Historické sociologie má rovněž zahraniční člen redakční rady našeho periodika David Inglis. Operativně spolupracovali i další spoluautoři (např́iklad Jiří Šubrt nebo Adam Coman).

Zcela na závěr zbývá vyslovit obvyklé přání, aby čtenářkám a čtenářưm přítomného čísla Historické sociologie přinesly publikované příspěvky inspiraci a podněty pro jejich vlastní badatelskou práci. Působilo by však jistě značně namyšleně a přehnaně, kdybychom hned očekávali, že na tomto základě se na takto inspirované př́íznivce našeho časopisu jako mávnutím kouzelného proutku odněkud shora snese zmiňované flow.

Bohuslav Šalanda

\section{Literatura}

Alieva, Dilbar [2015]. Dobrodružstvo z pohladu sociológie každodennosti. In. Sociológia každodennosti. Bratislava: Sociologický ústav SAV, s. 131-170.

Belgrad, Daniel [1998]. The Culture of Spontaneity: Improvisation and the Arts in Postwar America. Chicago: Chicago University Press.

Csikszentmihályi, Mihaly [1990]. Flow: The Psychology of Optimal Experience. New York: Harper Perennial. Csikszentmihályi, Mihaly [2016]. Flow: O štěstí a smyslu života. Praha: Portál.

Newton, Francis [1959]. The Jazz Scene. London: Macgibbon \& Kee.

Newton, Francis [1973]. Jazzová scéna. Praha: Supraphon.

Merton, Robert K. [2000]. Studie ze sociologické teorie. Praha: Sociologické nakladatelství.

Rychlík, Jan [1959]. Pověry a problémy jazzu. Praha: Státní nakladatelství krásné literatury a umění. Simmel, Georg [1997]. Peníze v moderní kultuře a jiné eseje. Praha: Sociologické nakladatelství.

Simmel, Georg [2003]. O podstate kultúry. Bratislava: Kaligram.

Turner, Victor [1982]. From Ritual to Theatre. The Human Seriousness of Play. New York: PAJ Publications.

Turner, Victor [2003]. Frame, Flow and Reflection: Ritual and Drama as Public Liminality. Japanese Journal of Religious Studies 6 (4): 465-495. 